\title{
JUURNAL_RU
}

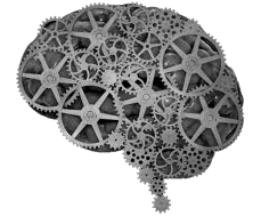

COMPANY GROUP "INTELLEKT"

\author{
Варламов А.С. \\ Челябинский государственный педагогический университет \\ Челябинск, Россия
}

doi: 10.18411/lj2016-3-49

\section{Современное состояние проблемы формирования ценностно-смысловых компетенций у курсантов военного вуза}

Согласно Федеральному государственному образовательному стандарту по направлению подготовки 161002 «Летная эксплуатация и применение авиационных комплексов» курсанта в военном вузе готовят к следующим видам профессиональной деятельности: эксплуатационно-технологической, организационно-управленческой, научно-исследовательской, учебнотренировочной [5]. Требования к результатам освоения основных образовательных программ подготовки специалистов выражены через совокупность компетенций (общекультурных, профессиональных, профессионально-специализированных). Эти требования определяют способность и готовность курсантов применять знания и умения на практике в процессе подготовки будущих офицеров.

Процессы актуализации содержательных и процессуальных аспектов образования курсантов военного вуза связаны с необходимостью формирования у них как у будущих военных специалистов ценностно-смысловых компетенций, которые относятся к ключевым (профессиональным). Для решения этой задачи необходимо разработать совокупность условий их реализации. К таким условиям следует отнести не только готовность курсанта к постоянным изменениям в службе, но и способность к свободному самоопределению, 
саморазвитию, проявлению любознательности и инициативы, самостоятельному выбору ценностно-смысловых предпочтений.

Формирование ценностно-смысловых компетенций связано со способностью обучающихся выбирать целевые и смысловые установки для своих действий и поступков, связанных с изучением окружающего мира, осознанием своих проблем, принимаемых решений. Решение актуальных проблем и задач зависит от потребности и мотивов выполнения всех видов деятельности по овладению необходимыми умениями, способами владения ими.

Изученная литература по проблеме формирования ценностно-смысловых компетенций, убеждает в том, что проблема разработки способов и средств (технологий) их формирования $\mathrm{y}$ курсантов военного вуза требует дополнительного изучения и исследования не смотря на то, что ей посвящено значительное количество работ педагогов (И.А. Зимняя, А.В.Хуторской, Н.В.Кузьмина, А.К.Маркова, А.П.Тряпицина, Ю.Г. Татур, Э.Ф. Зеер, С.В. Шишов, В.А. Кальней и др.) Ценностно-смысловые компетенции рассматриваются исследователями $\mathrm{c}$ разных позиций: психологического обоснования их особенностей формирования и освоения; условий реализации способов функционирования; результатов использования [2]. Неоднозначность в понимании педагогами сущности понятий «ключевая компетенция», «ценностно-смысловая компетенция» привела к необходимости их анализа с целью определения собственных позиций в их понимании. Учитывая тот факт, что ценностно-смысловые компетенции относятся к ключевым, раскроем их содержание.

И.А. Зимняя ключевые компетенции рассматривает как новую парадигму результатов образования [1]. Она сравнивает ее с той, которая долгое время существовала (середина, конец XX века, начало XXI в.) и провозглашала ЗУН парадигму результатов образования, включающего теоретическое обоснование и определение иерархии их умений и навыков, методик их формирования, контроля и оценки. Изменение целей образования, обусловленных вхождением 
человека в социальный мир, требующий не просто знаний и умений, а готовности применять их в новой ситуации. ЗУВ - парадигма образования, ориентированная на личностный, социально-интегрированный результат, выражается новым понятием «компетенция-компетентность».

В определениях ведущих педагогов компетенций и компетентностей нет единой точки зрения. Думаем, что разногласия в понимании сути этих понятий заключаются в неодинаковой исходной позиции, а именно в выборе основания для их классификации. Изучив основные определения, которые представлены в литературе в качестве ведущих, мы выбрали точку зрения Ю.Г. Татур [4]. Приведем его определения:

Компетенция - готовность (способность) к успешной (продуктивной) эффективной деятельности с учетом ее социальной значимости.

Компетентность - качество человека, завершившего образование определенного уровня, выражающееся в готовности (способности) на его основе к успешной деятельности с учетом ее социальной значимости и социальных рисков.

Классифицируя компетенции И.А. Зимняя условно поделила их на три группы и выделив десять ключевых компетенций:

I. компетенции, относящиеся к человеку как личности, субъекту деятельности, общения (ценностно-смысловая, здоровьесбережения, гражданственности, самосовершенствования и саморегуляции, личностной и предметной рефлексии);

II. компетенции, относящиеся к социальному взаимодействию человека с социальной средой (компетенции социального общения);

III. компетенции, относящиеся к деятельности человека (компетенции деятельности, информационных технологий).

И.А. Зимняя приходит к выводу, что ключевые компетенции - это общее и широкое определение адекватного проявления социальной жизни человека в современном обществе. Такие ключевые компетенции, по ее мнению, включают, 
способность эффективной работы в команде, планирование, разрешение проблем, творчество, лидерство, предпринимательское поведение, организационное видение и коммуникативные навыки. Проведенный анализ показывает, что в настоящее время образование столкнулось с достаточной трудной и неоднозначно решаемой исследователями задачей определения как содержания этого понятия, так и оснований разграничения ключевых компетенций и объема входящих в них компонентов. Это, в свою очередь, затрудняет разработку подходов (процедур, критериев, инструментов) к их оценке как результату образования [1].

Заслуживает внимания точка зрения А.В. Хуторского, который определил компетенцию (в том числе ключевую) как требование к образовательной подготовке, выражающееся смысловыми ориентациями, знаниями, умениями, опытом деятельности обучающегося в рамках личностно и социально-значимой продуктивной деятельности [6]. Им выделено семь групп ключевых компетенций: ценностно-смысловые, общекультурные, учебно-познавательные, информационные, коммуникативные, социально-трудовые, личностного сомосовершенствования.

Ценностно-смысловую компетенцию А.В Хуторской определяет как способность обучаемого видеть и понимать окружающий мир, ориентироваться в нем, осознавать свою роль в его преобразовании, уметь выбирать целевые установки для своих действий, принимать самостоятельные решения [6].

Для сравнения приведем примерный перечень ключевых компетенций для Европы [3] в форме, выделенных важнейших понятий: изучать; искать; думать; сотрудничать; приниматься за дело; адаптироваться.

Ценностно-смысловая компетенция, как компонент ключевой, относится к базовым компетенциям личности. Важно отметить, что производным от термина «компетенция» выступает понятие «ключевая (базовая)» компетенция. Базовыми можно назвать такие компетенции, которыми, во-первых, должен 
обладать каждый человек, а во-вторых, которые можно было бы применять в самых различных ситуациях.

Ценностно-смысловые компетенции предполагают наличие у обучаемого умений формулировать собственные ценностные ориентиры. Применительно к курсантам, к предмету и сферам военно-образовательной деятельности, владение способами самоопределения, выбором собственных позиций, умение быстро принимать решения в сложной обстановке, способность брать на себя ответственность за их последствия, готовность осуществлять действия и поступки на основе выбранных целевых и смысловых установок и составляют сущность ценностно-смысловых компетенций.

Ценностно-смысловая ориентация курсантов военного вуза осуществляется в процессе стимулирования мотивационно-ценностных, интеллектуальных и физических его составляющих, направленных на самосовершенствование личности. Ведущей идеей при этом выступает доступность получения знаний, формирование мотивации усвоения главных базовых ценностей жизни. Для реализации вышеуказанной идеи необходимо создать благоприятные воспитательные условия, направленные на усвоение курсантами основ ценностно-смыслового понимания военной службы, овладения навыками решения важнейших проблем и закрепления их в повседневной жизнедеятельности.

В заключении отметим, что педагогическая сущность формирования ценностно-смысловых компетенций заключается решении важной профессиональной задачи - реализации стремления курсанта военного вуза стать высококвалифицированным специалистом, принести пользу вооруженным силам и государству в целом. 


\section{Литература:}

1. Зимняя, И.А. Ключевые компетенции - новая парадигма результата образования /И.А.Зимняя// [Электронный ресурс] / - сайт Российского государственного гуманитарного университета /Режим доступа: http://aspirant.rggu.ru/article.html (50758байт).

2. Исаева, Т.Е. Классификация профессионально-личностных компетенций вузовского преподавателя/Т.Е.Исаева// Педагогика. - 2006. - № 9. - с. 5560.

3. Совет Европы: Симпозиум по теме «Ключевые компетенции для Европы»: Док. DECS/SC/Sec (96) 43. Берн, 1996.

4. Татур, Ю.Г. Компетентность в структуре модели качества подготовки специалиста/Ю.Г.Татур// Высшее образование сегодня. - 2004.- №3.- с. 2026.

5. Федеральный образовательный государственный стандарт высшего профессионального образования, 2011.- 56 с.

6. Хуторской, А.В. Современная дидактика: учебное пособие./А.В.Хуторской. - М.: Высшая школа, 2007.- 639 с. 